\title{
Sobre os autores
}

Teresa Chirico graduou-se em Música e Letras na Universidade La Sapienza, em Rome e atualmente é professora do Conservatório L. Refice, em Frosinone (Itália). Vários de seus ensaios foram publicados pelos periódicos: The Galpin Society journal; Nuova Rivista Musicale Italiana; Recercare; Le fonti musicali in Italia; Analecta musicologica; Studi Musicali, Rivista Italiana di Musicologia.

Ligiana Costa possui graduação em Musica pela Universidade de Brasília (2000), mestrado em Filologia dos textos musicais medievais e renascentistas pela Faculdade de Musicologia de Cremona (2004) e doutorado em Musicologia Universite de Tours (Universite Francois Rabelais) (2008). Tem experiência na área de Artes, com ênfase em musicologia, atuando principalmente nos seguintes temas: amas de leite, opera veneziana, commedia dellarte, musica barroca e teatro.

Marcie Ray é professora assistente de musicologia na Michigan State University College of Music (EUA). Possui bacharelado em performance vocal pela University of Texas e completou seu M.M. e Ph.D. na University of California, Los Angeles. Tem apresentado e publicado trabalhos em conferências e periódicos internacionais, tais como American Society for Eighteenth-Century Studies, Group for Early Modern Cultural Studies, and Feminist Theory and Music. Seus interesses de pesquisa incluem assuntos como música oderna e contemporânea, estudos de gênero, teoria da performance, teoria do cinema e teoria cultural.

Denise Scandarolli possui doutorado em História pela Universidade Estadual de Campinas (Unicamp) e doutorado com menção honrosa - Très Honorable avec félicitations - em Musicologia pela Université Paris IV-Sorbonne (2013). Concluiu o mestrado em História pela Unicamp, em 2008 e graduou-se em História, na Unicamp, em 2005. Atualmente é docente/pesquisadora do curso de História e de Música, do Unasp-EC, onde ministra aulas de História Moderna e História da Música (Da Renascença ao final do século XVIII). Fez parte da comissão organizadora do curso de História do Unasp-Engenheiro Coelho (2008), e do corpo docente de elaboração do curso de pós-graduação em História, do qual é 
atualmente coordenadora. Atua como pesquisadora em um grupo de pesquisa da Universidade Federal do Paraná (UFPR) de vertente multidisciplinar entre História Moderna e Musicologia. Tem experiência na área de História com ênfase em História Moderna e Contemporânea. Atualmente trabalha com o discurso ideológico construído pelo teatro marginal das feiras parisienses durante o século XVIII e com os diálogos mantidos por eles com os literatos do período.

Maria Birbili estudou piano, voz e literatura francesa na Sorbonne IV, e musicologia e estudos teatrais na Freie Universität Berlin. Sua tese, Die Politisierung der Oper im 19. Jahrhundert está no prelo pela editora Peter Lang, Frankfurt in 2014 (na série Perspektiven der Opernforschung, ed. Jürgen Maehder e Thomas Betzwieser). Maria Birbili é associada à Gerda Henkel Stiftung e ao DAAD na Itália e em Paris é chercheur associé à Maison des Sciences de l'Homme, e Visiting Scholar na University of Chicago, onde colabora com os projetos de edição crítica da obra de Rossini, Verdi, e Meyerbeer. Suas publicações são predominantemente em francês e italiano e sobre a ópera do séculos XVIII e XIX. 